УДК 821.111.1.09:821.161.1.09

UDC 821.111.1.09:821.161.1.09

DOI: $10.17223 / 19986645 / 57 / 15$

\title{
Yu.A. Tikhomirova
}

Tomsk State University (Tomsk, Russian Federation)

E-mail: yat77@mail.ru

\section{TRANSLATING A FACT, CREATING A MYTH: ROSA NEWMARCH'S IMAGES OF RUSSIA*}

\begin{abstract}
The article explores a relatively new domain of poetic translation - vocal (or music-linked) translation, through the study of translations made at the beginning of the twentieth century by the British poet and writer Rosa Newmarch, who began translating Russian poetry into English due to her professional interest in Russian music. A case study of two vocal translations is used to demonstrate how the poetics of translations are affected by the existence of their musical embodiments.

Keywords: poetic translation, vocal translation, translation shifts, Russian poetry in English, Rosa Newmarch.
\end{abstract}

The turn of the twentieth century was an unusual period in British-Russian cultural relations. In spite of the diplomatic tension grounded in rivalry in the international arena, the flourishing of Russian music and art led to the rise of interest on behalf of both British cultural activists and the public. Cultural recognition and appreciation in general were also facilitated by Russian émigrés in Britain and America who translated Russian poetry and prose, published books, and lectured on Russian literature. Diagilev's "Russian seasons" arrested the attention of ballet and music lovers, prompting an overall favorable response to Russian culture.

Thus, the cultural and translational activities of Rosa Harriet Newmarch (1857-1940), a poet and writer, musicologist, and translator, were within the general trend of a marked interest by the British in Russian culture. Newmarch's translation activities, spurred by the appreciation of Russian music (on which she wrote and lectured extensively), evolved into a lifetime adventure of search for self-identity and self-expression, as I will try to show.

Newmarch's translations of Russian art songs were originally made to demonstrate the best specimens of Russian vocal music, and her translations from Russian classical poetry followed The latter were presented in her book Poetry and Progress in Russia in 1907 as illustrations of the poetics of A. Pushkin, V. Zhukovskii, I. Kozlov, and M. Lermontov [1].

\footnotetext{
* This work has been done in the framework of TSU Competitiveness Enhancement Programme 2013-2020.
} 
Apart from Russian art songs, Newmarch is known to have introduced Russian folk pieces into English singing repertoire. Her "Ei, Ukhnem" "'Song of the Haulers on the Volga"), "Sredi Doliny Rovnyia" ("Amid a Lowland Valley Green"), and "Utushka Lugovaia" ("Duck of the Meadows") were published with musical scores [2]. For instance, the beginning of "Ei, Ukhnem" can be perfectly sung to the same melody as the Russian text, and sounds like this:

Pull a-way lads, pull a-way lads,

A long strong pull all to-ge-ther..

Her translations from Russian bespeak both the poetic talent and the utmost musicality of the author. They are distinguished by unique harmony and masterful command of poetic form, although not all of them are identical in translation approaches. Newmarch's undoubtedly keen sense of language, style, and rhythm are apparent through the conscious diversity of translation strategies: some of translations show a very high degree of fidelity to original poems in both form and meaning, others are overtly adapted for English-speaking readers. This approach, apart from the influence of English poetic tradition, indicates a conscious intention to "transplant" Russian originals onto English soil, and make them part of English-speaking word culture, "of which she herself was independently part" [3. P. 399].

In her review of Horae Amoris: The Collected Poems of Rosa Newmarch [3], Catherine Brown validates the high cultural and historical value of Newmarch's poetic oeuvre, along with elucidating the connection of her translation poetics with the English poetic tradition, thus making intelligible some startling aspects of her translation shifts. Philip Ross Bullock, in turn, explores Newmarch's background in aestheticism, for which she was largely indebted to Walter Pater, and centers his discussion on her adherence to inter-art analogies and the notion of reciprocal influence of art forms that informed her literary techniques in prose writing [4].

A solid point of departure for this inquiry is also provided by the introduction of John Holmes and Natasha Distiller, the editors of the recently published collection of Newmarch's poems [5. P. 13-48]. Exploring Newmarch's translations, Holmes and Distiller ground her choice of poems for translation in her life-building program and prove her translations to be an interpolation to and an extension of her original poetry. Also, they mention a vitally important fact of Newmarch's creative program, namely, that poetry, including translations, had no hard demarcation line with music, and that music was profoundly associated with Russia [Ibid. P. 35]. This love triangle with no odd element dominated Newmarch's poetic activities until 1917, when her interest in Russia lessened after the October Revolution and she turned to studies in Czechoslovakian music.

Yet, there is another important fact to complete the points of departure for this paper. Rosa Newmarch has been discussed for her queer poetics, and Holmes and Distiller make a point about it in the introduction [Ibid. P. 16-34]. According to them, it is most explicit in Newmarch's original sonnet sequences and less obvious in her translations. In search of her identity as a love poet, she 
explored the possibilities of self-expression in the Petrarchan sonnet tradition, which had been inherently the tradition of men's love poetry addressed to an idealized, unavailable woman. Engaging herself with this tradition, poetically expressing the unrequited passion for a woman, or, rather, women, as we encounter several in all her sonnet sequences, she aroused talk by her readers of lesbian love and even prompted attempts to find a real prototype of Newmarch's beloved among her contemporaries. This had nothing to do with her reality but was relevant only to her poetic imagination and the emotional aim of her sonnet sequences.

Still and all, to my knowledge, the present article is the first view of Newmark's work by an insider in the Russian cultural tradition and explores Newmarch's translations from a slightly different standpoint than previous works by mostly British scholars. It exploits tools of imagological research along with comparative study of translations and their originals, with elements of musicological analysis to elucidate the changes in the poetics of translation of texts that are aimed at vocal presentation and are closely associated with Newmarch's awareness of their existing melodies.

The most striking aspect of Newmarch's creativity is the choice of poetic texts (complete ones or fragments). More than two-thirds of forty-four translations from Russian are bound with music in one way or another. The great bulk of the texts had had a real melody, being art songs set to music by renowned Russian composers: Glinka, Tchaikovskii, Dargomyzhskii, Balakirev, RimskiiKorsakov, Rubinshtein, Viardo, and others, and, as a musicologist, Newmarch could not but know all of these vocal pieces.

Here belong A. Pushkin's "Eastern Song," "The High Road in Winter," A. Tolstoi's "The Ballroom meeting" and "A Benediction," Maikov's "Lead Me, O Night" and "Modern Greek Song," A. Plescheev's "Night," E. Baratynskii's "Elegy," A. Zhemchuzhnikov's "The Desert," A. Kol'tsov's "Come to Me," "Song" ("Nay, my lips may not tell"), M. Lermontov's "Prayer," "Circassian Song," "The Dream" ("At noon, in the valley of far Daghestan"), "The Palm Branch of Palestine," "Lines to - ," and V. Zhukovskii's "To a Floweret" and his dramatic song "The Midnight Review." Both "Tatyana's Letter" and "The Prophet" were also set to music, the former by P. Tchaikovskii in his opera "Evgeny Onegin," the latter as an arioso by N. Rimskii-Korsakov. Others have imaginary melodies, and are named for vocal genres such as songs and serenades, including A. Kol'tsov's "A Song of Olden Times", N. Nekrasov's "The Convict's Song", and N. Minskii's "Serenade."

Some of the translated texts seem to have no direct reference to music at first glance. "The Demon's Consolation to Tamara," Newmarch's translation of a fragment from M. Lermontov's "The Demon," bears no reference to music in the title. Nonetheless, the study of its poetics bespeaks the highest degree of the text's harmony and musicality; its soothing rhymes and particular rhythm, together with an abundance of parallel constructions and alliterations, clearly make this text a song, or, rather, a spell, a lullaby. Presenting this excerpt in Poetry and Progress in Russia, Newmarch notes that the words in which the De- 
mon consoles Tamara "are indeed a little commonplace in sentiment, yet thanks to the poet's art - as exquisitely musical as anything in the Russian language" [1. P. 97].

There are still other ways to refer to music in text that have no direct musicality involved: A. Khomiakov's "Lines written in Glinka's Album" conveys the whole range of associations brought forth by the name Glinka, one of the composers whom Newmarch, after Cui, named "the Father of Russian song," and highly favored his music and gave him a garland in art song writing [6. P. 377].

Ivan Krylov's "The Quartet," a satirical piece about "musicians", a mockery of people who have attempted to engage themselves with things they are not suited or unskilled for, turns, under Newmarch's pen, into a lecture on music, due to the disproportion caused by the four short lines in the original turning into the whole 10-line stanza voiced by the nightingale in translation. What is more, there are several texts that, as I argue, were not translated by Newmarch in full because of her propensity to behold real or imaginary music in any piece of poetry. This, of course, requires changes in a text structure and length, as lyric song is a genre that is much more emotional and suggestive than lyric poetry in general. That is how Pushkin's "The High Road in Winter" comes to lose three of its seven stanzas, becoming a nice, short, and quite dynamic song, as does his "Eastern Song" in Newmarch's translation.

No doubt, the type of text under translation depends greatly on the function of the collection it was aimed at. It is much more likely that we can find art songs in The Art Songs of Russia collection rather than in Poetry and Progress in Russia. Yet, even in the latter, which, by universal consent of scholars and Newmarch's own words in the introduction, was aimed at giving an account of the most influential Russian poetry, the rate of "musical" texts is much higher than would be generally expected, with some of the texts being unpopular or unknown even among Russian readership. Some of the texts included in Poetry and Progress in Russia could not be representative of Russian writers' poetics; clearly, they attracted Newmarch for other reasons. Such is, for instance, Lermontov's "The Nun's Song”, a piece of an earlier version of "The Demon" that is absent in a later version and, consequently, unknown to the wide public.

Another passage translated from M. Lermontov, "The Deserter. A Legend of the Caucasus," includes a large piece that presents an inserted song called "Selim's Song". Importantly, "Selim's Song" was made into an oriental song by M. Balakirev, although Newmarch chose to translate not only the song itself but also the context from which it was taken [7].

To conclude my general comments on Newmarch's "Russian" oeuvre, it is after this inventorying of Newmarch's translations from Russian (in light of their musical engagement) that a general statement by Distiller and Holmes acquires full sense and can be extended. The poet-translator drew no hard line between poetry and music [5. P. 35]. Moreover, she perceived poetry through music and translated mostly those pieces that could linger in her head, supported by their real or even imaginary melodies. 
Thus, Rosa Newmarch, not the first, but definitely one of the most productive and talented translators of Russian poetry into English, brought vocal translation, as I will argue, to a new, almost unattainable level. Vocal translation, a syncretic art, is one of the most complex and sophisticated types of aesthetic activities. When a text is linked to music (there exists another term, musiclinked translation, or MLT), the quality of perception of a poetic text undergoes tremendous change. To agree with the melody and satisfy its primary aim - to render audio-textual images, to enhance their complex perception by a listener translations of such texts ought to be not merely poetic translations. The most obvious requirement of such translated texts is to allow singing to the same music without clear disruptions in the rhythm; the dynamic stress should be on the proper syllables assigned by the logic of musico-verbal interrelationship. Still, translators must take into account much more than that: when the music creates an image, the text has to follow; when the text creates an image, music must support it and allocate the proper emphasis to the elements that bear the largest semantic burden, which are capable of bringing the meaning and the artistic value of the text across to the listener. Everything above is of particular importance for art songs. Because of the artistic nature of this genre, its utmost characteristic feature is the full merging of music, text, and voice.

Although it was a reality and everyday practice for Newmarch at the beginning of the twentieth century, vocal translation has only recently acquired scholars' support as a separate subject of poetic translation. This idea has been increasingly emphasized in works on translation in which scholars began to acquire understanding of the philosophical and psychological foundations of translation, along with the expansion of translation practice. Among scholars supporting the idea of a special status for vocal translation are M.P. Alekseev [8], D. Gorlee [9], M. Snell-Hornby [10], and P. Newmark [11]; all of them have made significant contributions to theoretical and/or practical exploration of the phenomenon. Yet, vocal translation remains terra incognita in translation studies. The low degree of theorization in vocal translation research may be partially due to the complexity of the subject, which requires a wide, cross-disciplinary approach.

The question arises whether it is at all necessary to make translations of vocal pieces if they can be, and often are, performed in the original language. Despite the longtime argument on whether music is a special language capable of rendering more than pure emotions, in modern scholarly, particularly musicological, discourse, the answer is rather no than yes, in the sense that music can enable listeners to imagine pictures and meanings evoked by music, but not to comprehend or see them clearly. Scholars are quite unanimous in accepting the fact that any vocal performance begins with a close philological overview of the text in the vocal piece to be presented. Discussing this question, Peter Newmark points out that there are two (I would say, at least two) aims for making vocal translations [11. P. 59-60]. Because vocal performance is an expressive art, per-

${ }^{*}$ See Langer [12], Cooke [13]. 
formers must ascertain their understanding of the text imagery. On the other hand, for the audience not to find themselves in a difficult situation when they have to take for granted the beauty and strength of the imagery rendered through some cryptic language, they must understand the words. And not only to understand (as mere understanding can be ensured through subtitles or surtitles, or interlinear translation in the program, for instance, which is not necessarily poetic), but they are to feel how words are attuned to music and how they merge with it, creating a meaningful whole [11. P. 59]. Thus, whatever Newmarch intuitively felt righteous to do with poetry that had musical support has become a universal truth almost a century later, and in this respect she is certainly a forerunner of this now generally accepted translation method.

Another important observation made by Holmes and Distiller that, in Newmarch's consciousness, music was profoundly associated with Russia, or, rather, Russia was associated with music, also presents itself when cataloguing her oeuvre. The image of Newmarch's Russia is of a singing country where everyone expresses their world perception through songs: mowers, gentry, convicts, and, of course, lovers of all sorts, to imply no irony. Music and song are the most natural way of expressing all the range of possible human feelings and emotions. Such a perception of Russia, as Distiller and Holmes note, correlates closely with Newmarch's image of Russia as a country where wild and unruly instincts can be naturally expressed beyond "formal social codes" [5. P. 45], and the queer poetics of her original poetry and her search for the means to voice the pain of unrequited love can be noted here.

Two questions arise from the observations above. The first is, what are we left with apart from the musical (mostly, vocal, as I will show later) translations? The second is, how does the fact that they are musical (vocal) translations affect their quality?

The answer to the first one seems quite obvious. Newmarch's Nadson, for instance, is thematically and especially emotionally very close to the atmosphere of the sonnet sequence "In Modo Tristi". Figuratively speaking, translating him, she translated herself. Also, she paid tribute to several "exclusively Russian" poets and themes that could be of particular interest to the British public due to the obvious national coloring: I. Nikitin, a Slavophil A. Khomiakov, and others*

To answer the second question, a close comparative study had to be undertaken. The choice for this case study was the translations that are most evidently associated with their music in Newmarch's consciousness. The two translations to be discussed here are "Elegy" from E. Baratynskii [Ibid. P. 182] (set to music by M. Glinka in 1825) and A. Tolstoi's "A Ballroom Meeting" [5. P. 229] (the music by P. Tchaikovskii, 1878). To begin with, both original texts have different names from those given by R. Newmarch. E. Baratynskii titled his text "Razuverenie" (1821), whereas A. Tolstoi's poem is named by its first line: "Sred' shumnogo bala..." (1851). Both texts were first published in New-

\footnotetext{
${ }^{*}$ For more on this see [5. P. 47-48].
} 
march's collection Art Songs of Russia and later reprinted in Poetry and Progress in Russia in her discussion of Russian poets.

Glinka's art song to Baratynskii's lyrics hasproved to be so popular in Russia that it supplanted the poem itself; it is even hard to remember the real title of the poem, as the art song is titled by the first line. Newmarch chooses to give her translation a genre name, Elegy, which is commonly recognized to be a poetic genre equivalent to the musical genre of art song.

Because this was one of Glinka's most effective art songs by the universal consent of musicologists, the essence of Baratynskii's poem changed quite significantly. At first look, the poem is basically about a heart that is dying emotionally, about a bitter disillusionment in life and love, and sweet oblivion that the heart longs for.

Baratynskii does not divide stanzas graphically; however, the text is clearly divided into two parts. The starting point for the development of Baratynskii's lyric plot is a rebuff expressed in imperatives (ne iskushai, ne mnozh, ne zavodi, ne trevozh). Then, the rebuff is followed by a subtle analysis and dissection of emotions. Exactly the same structure is repeated in the second part of the poem.

In Glinka's two-part art song with a clear $a b a b$ structure, the sentimentality and excitement of a lyric hero burst out in the $b$-parts in C-major, bringing joyful and even playful intonations, and this significantly complicates the interpretation of the poem as the confession of a dying heart. In addition, the recitative melody in the $a$-parts changes to a lively arioso melody in the $b$-parts, and cantilena penetrates it, involving stressed and unstressed vowels in cantuses. The heart of the lyric hero revives; as B. Asafiev, a musicology professor and composer, notes, "The negations in this Baratynskii's poem actually conceals a wish: I wish temptations, wish to daydream, I wish to believe in love. A surrendering obedient heart still yields challenges", [14. P. 252]. The real meaning of the poem becomes evident through Glinka's music.

Newmarch's translation, no doubt, was made from Glinka's art song, not Baratynskii's poem per se. Apart from the title corresponding to Glinka's art song rather than to Baratynskii's poem, there is more evidence: Newmarch's translation is graphically a two-part piece, and the translated text contains the same changes that Glinka made in it for his own artistic purposes (for instance, "nemoe stradanie" [silent anguish] instead of "slepoe stradanie" [blind anguish]).

Newmarch was aware of the architectonics of the contrastive parts of the art song. Emotional coldness and the death of the heart are intensified in the art song by the cold recitative melody in a minor key, and it bursts out in translation at the lexical level: "grown cold", "perished", "languish", "dead", "Too late..!" Baratynskii's images of daydream, oblivion, alienation from the pleasantries of life are explicitly replaced by images of death, grave coldness, in translation.

\footnotetext{
* All the translations of literature citations in this article are made by the author (Y.T.), unless stated otherwise.
} 
Interestingly, the emphasis shifts from the inability of the attempts of the lyrical subject's former beloved to revive his feelings about the impossibility of such attempts by anyone:

For even you may not discover

A charm to bring love back to life.

This emphatic "Even you" bespeaks the heart that is dead to any expression of feeling.

When the original exposes a high number of sonorants which alliterate the text creating a sound image of "sladkii son": "spliu," "sladko usyplenie," "byvalye mechty," "volnenie," "liubov'," Newmarch's ear discerns the importance of these audial images and employs equally notable findings: "I sleep; "tis sweet...", "A charm to bring love back to life." The strict alternation of alliterations in the translation of the last line creates an overwhelming expressiveness, emphasizing and multiplying the culminative effect of the final phrase by melodic replication.

Generally speaking, presented without its musical score, Newmarch's text does not produce the effect of an equivalent translation, because the translation exposes quite a different emotion; yet, the reasons for transformations become apparent through juxtaposition of the translated text and the musical setting.

Another case of Newmarch's translation being affected by the existing melody is Alexei Tolstoi's "Sred' shumnogo bala" (set to music by P. Tchaikovskii). Tolstoi's poetry has proved very attractive for composers because of its unique properties of poetics and the ultimate melodiousness of his texts. A good half of his poems have been set to music.

There are some preconditions to analyzing the translation. The poem is written in amphibrach trimeter, and is a perfect example of a pure meter with its ultimately regular sequence of measures and feet. There is not a single pyrrhic in the entire poem (which, of course, sets quite a challenge for any translator). The amphibrach, the classical meter for "water" plots (due to its balanced structure), is also associated with Russian balladic tradition, including Tolstoi himself [15. P. 180]. Using the amphibrach implies an important meaning: the moment of the ball meeting is presented as a romantic ballad, a halo of mystery, an enigmatic cover, something divine enters the picture.

The plot of the ball meeting and the amphibrach trimeter used by the poet gave Tchaikovskii ground to introduce the waltzing rhythm into the music. Although the waltzing meter is rather dactyl because of its first stressed foot, the use of an off-beat settles the matter, and the first unstressed syllable is perceived as the anacrusis. Together with the waltzing rhythm, the piece acquires "the squareness, periodicity, characteristic of dancing forms" [16. P. 85]. The art song is cemented by repetitive rhythmical phrases that are perceived as spinning, whirling in a dance.

The recapitulation shows new melodic turns emerging to render subtle shades of the development in the lyric plot. In regard to the lyric subject matter, 
Tolstoi's poem is divided into two parts: a recollection of the meeting at the ball (1-3 stanzas), and the lyric hero's introspective analysis of his own feelings regarding the Unknown Beauty (4-5 stanzas). This division is largely emphasized by means of poetics: the emergence of the visual image of the ball in the first part is greatly due to the sound imagery - the s, sch, tch alliterations, which create an audible image of dresses swishing in the dance, and the rustling of fans and curtains. In melody, the piece is narrated as a story of the meeting at the ball, with several stages of development: first, a beautiful unknown lady is emerging as a vision, hidden behind the curtain of mystery. The vision gradually acquires real features in the poetic text: her traits become clearer, there appear a "tonkii stan" [slender figure] and a "zadumchivyi vid" [pensive look]. In support of this change toward clear and tangible reality, the music breaks out in the Ddur (against h-moll as a principal tonality), at first in the way of a cadence, later as the main mode in the middle stanza [16. P. 115]. This third stanza, written in a major key, becomes the compositional center of the poem, after which there is a shift in the mood (in both the music and the text):

\author{
V chasy odinokie nochi \\ Lyubliu ya, ustalyi, prilech $<\ldots>$ \\ (In the lonely hours of night \\ Being tired, I like to lie down $<\ldots>$ ) \\ I grustno ia tak zasypaiu $<\ldots>$ \\ (And sadly I fall to sleep $<\ldots>$ )
}

The image of the beautiful unknown lady dissolves in a sad half-sleep, turning into a vision, and the music again supports this idea by reintroducing the melodic phrases that were characteristic of the beginning of the art song. The recapitulation (in the final stanza) irrevocably blurs the line between reality and half-sleep. These nuances are rendered through changes in the melody and harmony of the second phrase in the complex double period. The words "zasypaiu" ("I'm falling asleep"), "no kazhetsia mne, chto liubliu" (but I seem to love you) are accompanied by stiffening recitative musical phrases that arouse the feeling of torpidity, submerging into sleep, to substitute for lively arioso-like phrases characteristic of the first part. Thus, the music and the poetry create a common semantic field, interplaying at the level of poetics that are intrinsic to these two kinds of art.

The vital role of the melodic stress, that is, emphasizing a syllable by the height of pitch, is worth a special mention. The text involves additional accentuation of several particular elements (especially in the combination with the following caesura, which makes it even more emphatic). In this case, the strongest positions (of all the dynamically stressed elements) are occupied by the following: "bala" ("ball"), "sluchaino" ("accidentally"), "mirskoi" ("worldly"), "uvidel" ("saw"), "taina" ("mystery"), "pechal'no" ("sadly"), "divno" ("divinely"), "zadumchivyi" ("pensive"), "otdalennoi" ("remote"), "odinokie" ("lonely"), "ustalyi” ("tired"), "pechal'nye" ("grievous"), "grustno" ("sad"), "nevedomyh" 
("unknown) and it all resolves in "liubliu" ("I love"). This chain of lexemes arranges a very specific romantic line in this art song, as if to subdue all the other senses in this logic: the motif of a mystical cover, a curtain, inherited from the first Russian romantic poet Vasilii Zhukovskii, becomes especially clear and plot-binding only in interplay with the music. And the fact that this chain resolves into "liubliu" ("I love") cancels all the doubts explicated in the poetic text.

The study of Newmarch's "A Ballroom Meeting" to explore the influence of this syncretic semantic field on the translation has shown the following. Newmarch chooses to begin by describing the hustle and bustle of the waltzing ball ("noisy", "the whirl") with its glaring light and shimmering jewels ("glowing", "glare"). The picture is clearly suggested by the melody, not the original text itself, as there is no explicit description of the ball whatsoever in Tolstoi's poem, and the only adjective employed in the original is "shumnyi" (noisy). Newmarch develops this scene into a panoramic picture. Such perception appears quite characteristic of Newmarch: she saw music as musical pictures, and she described them in her texts in her capacity of a musical concert programme writer. Newmarch's peculiar syncretic perception of arts caused a number of translation shifts in the poetics and the imagery of the text. Thus, the audio-visual image of the ball reinforced by the music makes the image of a waltzing crowd burst out in the words of the translation: "We met in the whirl and the glare."

In the situation of the ballroom light and glare, Newmarch finds it important to emphasize the motif of peering. She adds "And gazed on your features..." that departs from the original, for in the latter the dominating motif is of a mystical cover or a curtain. It prevents the lyric hero from seeing and distinguishing traits of the unknown beauty. Nonetheless, the logic of Newmarch's text justifies this transition, and the substitution of the motifs is perceived as being natural.

The description of the heroine's voice acquires a dramatically different tone in translation. The original compares it with "zvon otdalennoi svireli" ("the ringing of a distant flute"); in translation it becomes "fifes tuned to triumph and gladness" and "wavelets that laugh as they fall". The reason for such change clearly does not rest in the poetic text, but in the musical one. This very passage of the melody acquires a major tone, and the major chords begin to break though the minor melody, resolving in the full major of the next stanza. That is how "triumph" and "gladness" penetrate the translation, thus providing the necessary link of the poetic expression to the musical one.

Newmarch substitutes the description of the beauty's traits (slender figure, pensive look) by the lyric hero's pondering: "For joy of for grief are you fitter? / A vision of woe or delight?" These two questions become the compositional center of the art song in translation. The melody in the major key, making this stanza stand out from the rest of the poetic-musical text, emphasizes these doubts as the most important issues, ones which gather all the other poetic meaning around them.

As was mentioned above, it was quite natural for Newmarch to explicitly describe her musical impressions in words. The return to the minor in the fourth 
couplet of the art song produces an anticipated impression on Newmarch: the text is amplified by "solitude dreary" that appears on the account of the tonality that changes back to the minor. The darkness and solitude are emphasized through introducing additions "through the silence". Nevertheless, due to her professional ear for music, Newmarch manages to notice a concurrence of several types of stress (melodic and dynamic) on the word "love" and resolves all the doubts of the hero by employing the equivalent device in English.

To conclude, the rhythm of Newmarch's translation presents as clear and perfect an example of the meter as the original poem itself, with absolutely correct alternations of feet and verses. Like A. Tolstoi, Newmarch does not use a single pyrrhic, rather the rhythmical and metrical picture of the translation is completely identical to the original. Not a full semantic equivalent to the original poem, Newmarch's translation is clearly a good functional equivalent of Tchaikovskii's art song, and a brilliant English poem in its own right.

Rosa Newmarch's creative works are an apparent expression of her lifelong passions and pains: poetry that strives to become music, and music that assimilates poetry, erasing boundaries between the two arts, and a queer poetic voice conveying the pain of an unrequited love that can be fully and freely vented in an imaginary realm. Ascribing the features of a singing country to Russia, Newmarch seemed to be aware of the line between the real and the imaginary, having undertaken a study of Russian poetry in her Poetry and Progress. But the poetic texts, the most immediate expression of her artistic nature, flawed the attempts to classify, to prescribe, to draw boundaries, as she was too much a woman with an irrepressible stream of creative power, very much akin to the element of music itself.

\section{References}

1. Newmarch, R. (1907) Poetry and Progress in Russia. London: John Lane the Bodley Head, New York: John Lane Company.

2. Newmarch, R. (1917) Fourteen Russian Folk-songs with pianoforte accompaniment. Translated from Russian by Rosa Newmarch. London: J. \& W. Chester.

3. Brown, C. (2011). Review of "Horae Amoris": The Collected Poems of Rosa Newmarch. Edited by John Holmes and Natasha Distiller. 293 pp. (High Wycombe: Rivendale Press, 2010). Translation and Literature. 20(3). pp. 397-403.

4. Bullock, Ph.R. (2010) "Lessons in sensibility": Rosa Newmarch, Music Appreciation, and the Aesthetic Cultivation of the Self. The Yearbook of English Studies. 40(1/2). pp. 295-318.

5. Newmarch, R. (2010) Horae Amoris: The Collected Poems of Rosa Newmarch. High Wycombe: Rivendale Press.

6. Newmarch, Rosa. (1902) The Art Songs of Russia. Sammelbände Der Internationalen Musikgesellschaft. 3(2), pp. 377-387.

7. Tikhomirova, Yu.A. (2016) [Russian Poetry as a Musical Metatext: Singing Russia of Rosa Newmarch]. Russkii iazyk v polikkul'turnom mire [Russian Language in Polycultural World]. Procees of the X International Conference. 8-11 June 2016. Vol. 2. Simpheropol: IT "ARIAL". pp. 530-537. (In Russian).

8. Alekseev, M.P. (1981) Angliyskaya poeziya i russkaya literatura [English poetry and Russian Literature]. In: Alekseev, M.P. et al. (eds) Angliyskaia poeziia v russkikh perevodakh $(X I V-X I X$ veka) [English poetry in Russian translations (14th-19th centuries)]. Moscow: Progress. 
9. Gorlee, D. (ed.) (2005) Song and Significance: Virtues and Vices of Vocal Translation. Approaches to Translation Studies. 25. Amsterdam; New York: Rodopi.

10. Snell-Horbny, M. (2006) The Turns of Translation Studies: New paradigms or shifting viewpoints? Benjamins Translation Library. Amsterdam: Benjamins.

11. Newmark, P. (2012) Art Song in Translation. In: Minors, H.J. (ed.) Music, text and translation. (Bloomsbury Advances in translation). London: Bloomsbury.

12. Langer, S.K. (1953) Feeling and Form: a theory of art. NY: Charles Scribner.

13. Cooke, Deryck. (1959/2001) The Language of Music. Oxford: Clarendon Paperbacks.

14. Asafiev, B.V. (1978) M.I. Glinka. Leningrad: Muzyka. pp. 247-257. (In Russian).

15. Gasparov, M.L. (2000) Ocherk istorii russkogo stikha [Essay on History of Russian Verse]. 2nd ed. Moscow: Fortuna.

16. Ruchyevskaya, E.A., Ivanova, L.A. \& Shirokova, V.P. (1988) Analiz muzykal'nykh proizvedeniy [Analysis of Musical Works]. Leningrad: Muzyka.

\section{Переводя факт, создавая миф: образы России в творчестве Розы Ньюмарч* Ю.А. Тихомирова}

Ключевые слова: поэтический перевод, вокальный перевод, переводческие трансформации, русская поэзия на английском, Роза Ньюмарч.

Предлагается новый, междисциплинарный подход к исследованию переводческой деятельности Розы Ньюмарч, поэтессы, писательницы и музыковеда рубежа XIX$\mathrm{XX}$ вв., которая, начавшись с любви к русской музыке, эволюционировала в поиски путей самопознания и самовыражения через переводы русской поэзии. На материале английских переводов Ньюмарч из русской поэзии, предназначенной для музыкального воспроизведения (песни, романсы), исследуется проблема взаимосвязи переводческого выбора и метода с ее жизнетворческой программой; доказывается, что ее переводы являются продолжением как профессиональной музыковедческой деятельности, так и собственной оригинальной поэзии, где поэзия и музыка не имеют строгих границ, а музыка глубоко ассоциируется с Россией.

Инвентаризация переводов Ньюмарч из русской поэзии с позиций их принадлежности или соотнесенности с музыкальным контекстом выявила, что две трети текстов так или иначе связаны с музыкой. Обнаружено несколько типов связей: у некоторых существуют реальные мелодии, у других - воображаемые жанровые инварианты (они имеют жанровые названия - песня, серенада). Часть из них не имеют прямого отношения к музыке, но показывают высокую степень мелодичности текста: специфические ритм и рифма, стилистические приемы (параллельные конструкции, аллитерации и др.) делают их песенными. Остальные связаны с музыкой при помощи сюжета. Образ России Ньюмарч - образ поющей страны, где музыка - наиболее естественный способ выражения человеческих чувств.

Сосредоточившись на анализе переводов, имеющих реальную мелодическую основу, удалось доказать, что Ньюмарч воспринимала поэзию через музыку и наиболее адекватно переводила то, что имело свойство задерживаться в сознании при помощи мелодии. Сложность и комплексность материала, принадлежащего как литературоведческому и компаративному, так и музыковедческому полю, предопределили междисциплинарный подход к его изучению: комбинация имагологического, компаративного и музыковедческого видов анализа позволила выявить и объяснить переводческие трансформации в текстах, предназначенных для музыкального воспроизведения.

Изучение переводов Ньюмарч "Elegy" (романс Е. Баратынского - М. Глинки) и “A Ballroom Meeting” (А. Толстого - П. Чайковского) показало, что переводческие

\footnotetext{
* Настоящая работа выполнена при поддержке Программы повышения международной конкурентоспособности Томского государственного университета на 2013-2020 гг.
} 
трансформации возникли как результат комплексного восприятия музыкальнословесного произведения; среди изменений - графический облик стихотворений, лексические и фонетические изменения, подсказываемые мелодиями, сдвиги в эмфатических ударениях и т.д. Не будучи полными семантическими эквивалентами русских романсных текстов, переводы Ньюмарч являются их блестящими функциональными эквивалентами, рассмотренными в комплексе поэтико-музыкальных свойств. 